\title{
Analysis of the Effect of Service Quality on Corporate Image and Service Usage Decisions at PT. Biro Klasifikasi Indonesia (Persero)
}

\author{
Abdul Kholick ${ }^{1}$, Thomas Stefanus Kaihatu ${ }^{2}$, \\ ${ }^{I}$ PT. Biro Klasifikasi Indonesia, ${ }^{2}$ School Of Business and Management, Universitas Ciputra Surabaya \\ abdulkholick@gmail.com, \\ thomas.kaihatu@ciputra.ac.id \\ https://doi.org/10.37715/rmbe.v1i2.2418
}

\begin{abstract}
This study aims to determine the effect of service quality (X1) on corporate image (X2) and service usage decision (Y) of PT. Biro Klasifikasi Indonesia (Persero). The research approach taken is quantitative. The sampling technique used was non probability sampling with purposive sampling method. The number of samples in this study were 90 respondents with the criteria of consumers who have registered ships at PT. Biro Klasifikasi Indonesia and also has vessels registered with foreign classification agencies. The data collection method in this study used a questionnaire measured using a Likert scale and the data collected were analyzed Structural Equation Modelling with Partial Least Square. The program used is SmartPLS 3.0. Based on the results of the analysis that has been done, it is known that service quality has a positive and significant effect on the corporate image of PT. BKI, service quality has a positive and significant effect on the decision to use PT. BKI and corporate image have a positive and significant effect on the decision to use BKI.
\end{abstract}

Keywords - Service Quality, Corporate Image, Usage Decisions.

\section{Introduction}

Since the enactment of the regulation of the Minister of transportation no. 61 of 2014 regarding classification bodies that are recognized and registered with the government of the Republic of Indonesia, the greater the competition for PT. PT. Biro Klasifikasi Indonesia in requesting ship class acceptance is due to the increasing number of foreign classification bodies that exist in Indonesian territory. This can be seen in the construction of new ships owned by state-owned companies, Customs and the Ministry of Defense which were built using foreign classification bodies. In conditions of free competition as currently PT. Biro Klasifikasi Indonesia, which is the only national classification body, is required to be able to compete both in the national market and in the international market with foreign classification bodies. Therefore, PT. Biro Klasifikasi Indonesia is required to have a strategy in winning business competition, one of which is through a strategy of corporate image and service quality. In the perspective of TQM (Total Quality Management), quality can be seen from a broader perspective, which is not only oriented to the aspect of the end result that is emphasized, but also includes processes, the environment, and people. According to Yudiana dan Setyono (2016), the corporate's image as an overall impression that is embedded in the minds of customers as a result of accumulated feelings, ideas, attitudes, experiences with the organization that are stored in memory, are transformed into positive or negative meanings. It is a must for companies to be able to build a good corporate image and provide the best quality service for customers.

The hope from the results of this study is that it can provide information and considerations for implementing strategies by companies regarding the influence of service quality and corporate image on service usage decision. So that PT. Biro Klasifikasi Indonesia (Persero) can develop its business in the future, especially from the aspect of service quality and corporate image. And can be used as a reference for further research in conducting similar research.

\section{Literature Review}

2.1. Previous Research

Research of Rohman and Hatmawan (2018) entitled "Analisis Pengaruh Citra Merek dan Kualitas Layanan terhadap Keputusan Pengguna Jasa Pengiriman (Study Kasus pada Pengguna Jasa JNE Express Across Nations 
Cabang Nganjuk)". The results of the study found that Brand Image and Service Quality simultaneously or together had a significant influence on usage decisions in using shipping services. The second research by Keni et al., (2020) entitled "The Impact of Service Quality and Corporate Reputation toward Tourist Loyalty: A Study of the Indonesian Hotel Industry". This study was conducted to determine the effect of service quality and corporate reputation on tourist loyalty in the Indonesian hospitality industry. Based on the results of data analysis, the authors conclude that service quality and corporate reputation have a positive effect on tourist loyalty in the Indonesian hospitality industry.

Further research from Wilson (2019) with the title "The Impact Of Service Quality And Brand Image Toward Customer Loyalty In The Indonesian Airlines Industry". This research was conducted to determine and understand the effect of service quality and brand image on customer loyalty in the aviation industry in Indonesia. Based on the results of data analysis, it can be concluded that service quality and brand image have a positive effect on customer loyalty in the aviation industry in Indonesia, where service quality has a greater influence than brand image in influencing customer loyalty

\subsection{Theoretical basis}

\subsubsection{Service Quality}

Service quality is a condition in which the customer formulates the results of the comparison between the expectations of a product or service and the perceived acceptance of service performance (Fauzi \& Suryani, 2019). The service quality indicator used in this study uses the theory of Parasuraman et al. (1988, as cited in Parman \& Susanto, 2016) known as TERRA, they are as follows:

1. Tangibles (physical evidence)

2. Empathy (empathy)

3. Reliability (reliability)

4. Responsiveness (responsiveness)

5. Assurance (guarantee and assurance)

\subsubsection{Corporate image}

In his research, Omoregie et al. (2019) suggest that corporate image is a form of intangible asset in a corporate that has a uniqueness which is easy to identify but difficult to imitate. Corporate image is a set of meanings from customers where customers remember, describe, and relate the results of the experience into beliefs, memories, feelings, and knowledge (Giovanis et al., 2016). According to Harrison (1995, as cited in Pasaribu \& Agung E, 2015) suggests that complete indicators of corporate image include:

1) Personality (personality of the corporate)

2) Reputation (the reputation of the corporate)

3) Credibility (the quality that exists in the corporate)

4) Reliability (the potential or reliability of the corporate)

5) Trustworthines (the trust the corporate deserves)

6) Responsibility (the ability of the corporate to be responsible)

7) Value (plus value owned by the corporate that becomes)

8) Corporate identity (corporate identity for consumers)

\subsubsection{Usage Decision}

Usage decision theory is analogous to purchasing decisions, such as research conducted by Rahardjo (2017) which states that usage decision is the same as consumer purchasing decisions. According to (Kotler \& Keller, 2012, p. 154) there are four indicators of purchasing decisions, namely:

1. Stability in a product.

2. Habits in buying products.

3. Provide recommendations to others.

4. Make repeat purchases. 


\section{Research Methods}

\subsection{Analysis Model}

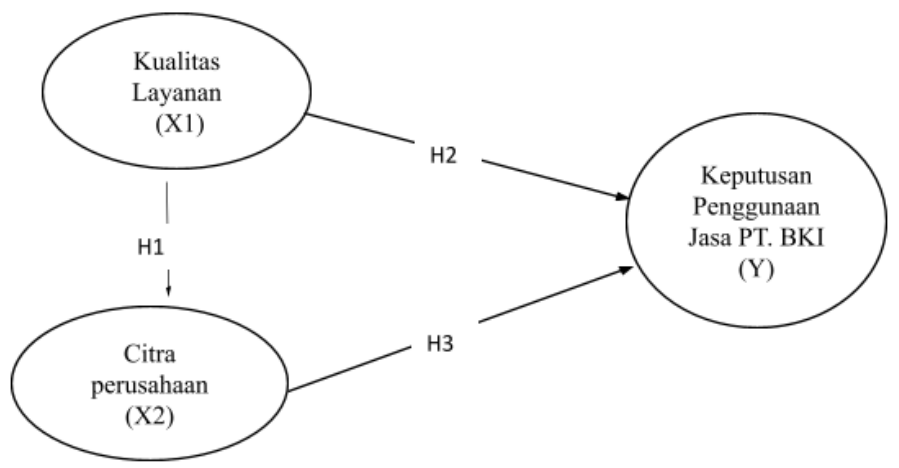

Figure 3.1. Analysis Model

Based on the formulation of the problem and the literature review that has been explained, the hypotheses in this study can be formulated as follows:

H1: Service quality has a significant effect on corporate image

$\mathrm{H} 2$ : Service quality has a significant effect on service usage decision

H3: Corporate image has a significant effect on the decision to use services.

$\mathrm{H} 4$ : Corporate image is suspected to mediate the relationship between service quality and service usage decisions

\subsection{Research Approach}

In this study the author uses quantitative methods, where according to $(2017$, p. 8$)$ quantitative research methods can be interpreted as research methods based on the philosophy of positivism, used to examine certain populations or samples, sampling techniques are generally carried out randomly, data collection using research instruments, data analysis is quantitative or statistical in nature with the aim of testing predetermined hypotheses. The population in this study are registered consumers using the services of PT. BKI. In this study, the selected sample is consumers who have ships registered at PT. Biro Klasifikasi Indonesia and also has ships registered with foreign classification bodies. In determining the data to be studied the sampling method used is nonprobability sampling. Non-probability sampling is a sampling technique that does not provide equal opportunities for each element or member of the population to be sampled. In determining the sample size, the researcher used the error rate developed by Isaac and Michael, including 1\%,5\%,10\%. Due to the large number of populations used by researchers, the researchers used an error rate of $10 \%$ (Sugiyono, 2017, p. 126).

Determine the sample size of a population with the formula (Slovin Formula):

$$
\mathrm{n}=\mathrm{N} /\left(\mathrm{N}(\mathrm{e})^{2}+1\right)
$$

$\mathrm{n}=$ sample;

$\mathrm{N}=$ population;

$\mathrm{e}=$ fault tolerance limit (precision value of $90 \%$ or significance of fault tolerance $=0.1$ )

$\mathrm{n}=887 /\left(887 \times(0.1)^{2}+1\right)$

$\mathrm{n}=887 / 9.87$

$\mathrm{n}=89.86$ rounded up to 90

The total number of respondents' population is 887 companies. So the sample taken as this study uses a $90 \%$ confidence level and an error rate of $10 \%$ is 90 samples.

In this study, the data collection method used was a questionnaire instrument. According to (Sugiyono, 2018, p. 142), the questionnaire is a data collection technique that is carried out by giving a set of questions or written statements to respondents to answer. The measurement data used in this study to measure the results of the questionnaire is a Likert scale. According to (Siregar, 2013, p. 138) the Likert scale is a scale that can be used to measure a person's attitudes, opinions and perceptions about a particular object or phenomenon. In this study, each question was measured by five scales with the following information:

- 1 = Strongly Disagree (STS) 
- $2=$ Disagree $(\mathrm{TS})$

- 3 = Disagree $(\mathrm{KS})$

- $4=$ Agree $(\mathrm{S})$

- $5=$ Strongly Agree (SS)

\subsection{Variable Operational Definition}

Table 3.1. Operational Definitions and Indicators of Service Quality Variables

\begin{tabular}{|c|c|}
\hline \multicolumn{2}{|c|}{$\begin{array}{l}\text { Service Quality } \\
\text { According to Stringham \& Gerdes (2019), service quality is how far the service can satisfy what is expected and needed } \\
\text { by customers. }\end{array}$} \\
\hline Reference & Indicator \\
\hline \multirow{5}{*}{$\begin{array}{l}\text { Parasuraman et al (1985) in } \\
\text { Parman and Susanto (2016) }\end{array}$} & KL1 : PT. BKI is quite complete and easy to use \\
\hline & KL2 : Employees of PT. BKI is always polite in providing services \\
\hline & KL3: Technical Staff / Surveyor who handles classification services correctly. \\
\hline & $\begin{array}{l}\text { KL4: Employees of PT. BKI always has the ability to respond/standby in responding } \\
\text { to requests/complaints. }\end{array}$ \\
\hline & KL5 : PT. BKI provides fast and precise service \\
\hline
\end{tabular}

Table 3.2. Operational Definitions and Indicators of Corporate Image Variables

\begin{tabular}{|c|c|}
\hline \multicolumn{2}{|c|}{$\begin{array}{l}\text { Corporate image } \\
\text { Corporate image is a set of meanings from customers where customers remember, describe, and relate the results of the } \\
\text { experience into beliefs, memories, feelings and knowledge (Giovannis et al. 2016). }\end{array}$} \\
\hline Reference & Indicator \\
\hline \multirow{8}{*}{$\begin{array}{l}\text { According to Harrison } \\
(1995: 71) \text { in Pasaribu (2015) }\end{array}$} & CP1 : PT. BKI always maintains the quality of the classification services offered \\
\hline & CP2 : PT. BKI has a good reputation in providing services \\
\hline & $\begin{array}{l}\text { CP3 : Quality of services and services of PT. BKI in accordance with customer } \\
\text { expectations }\end{array}$ \\
\hline & CP4 : Technical Staff / Surveyor of PT. BKI has sufficient experience \\
\hline & CP5 : I have high trust PT. BKI as a trusted classification body \\
\hline & CP6: PT. BKI cares about the development of research in the maritime field. \\
\hline & CP7: PT. BKI offers products at competitive prices. \\
\hline & CP8 : PT. BKI is a world-class national classification body \\
\hline
\end{tabular}

Table 3.3. Operational Definitions and Indicators of Usage decision Variables

Usage Decision
Raharjo (2017) which states that usage decisions are the same as consumer purchasing decisions. Purchasing decisions are
thoughts in which individuals evaluate various options and decide on a product from the many choices.

\section{Reference}

According to Kotler and Keller

$(2012: 154)$

\begin{tabular}{|l|}
\hline Indicator \\
\hline KP1 $:$ I use the services of PT. BKI because of the need \\
\hline KP2 $:$ I use the services of PT. BKI because of the fast and precise service \\
\hline KP3 $:$ I will recommend to others to use the services of PT. BKI \\
\hline KP4 : I will use the services of PT. BKI is back \\
\hline
\end{tabular}

\subsection{Data analysis}

The data analysis technique in this study used Partial Least Square (PLS). PLS is a Structural Equation Modeling (SEM) equation model with an approach based on variants or component-based structural equation modeling, Ghozali \& Latan (2015) The PLS-SEM analysis consists of two sub-models, namely the measurement model or the outer model and the structural model or the inner model.

\subsubsection{Descriptive Statistics Test}

Descriptive statistics are statistics that function to describe or provide an overview of the object under study through sample or population data as it is, without analyzing and making conclusions that apply to the public (Sugiyono, 2016).

\subsubsection{Test Measurement Model or Outer Model}

Evaluation of the measurement model through confirmatory factor analysis is using the MTMM (Multi Trait-Multi Method) approach by testing convergent validity and discriminant validity. While the reliability test was carried out in two ways, namely with Cronbach's Alpha and Composite Reliability (Ghozali \& Latan, 
2015). Convergent validity of the measurement model with reflexive indicators can be seen from the correlation between item scores/indicators and their construct scores. Individual reflective measure is said to be high if it has a correlation of more than 0.70 with the construct to be measured. However, at the research stage of the scale development stage, a loading of 0.50 to 0.60 is still acceptable (Ghozali \& Latan, 2015). The model is said to have a fairly good discriminant validity if the AVE root for each construct is greater than the correlation between constructs and other constructs (Fornell \& Larcker, 1981 in Ghozali, 2015). In Ghozali \& Latan (2015) describes another test to assess the validity of the construct by looking at the AVE value. The model is said to be good if the AVE of each construct is greater than 0.50 .

In addition to the validity test, model measurement was also carried out to test the reliability of a construct. In PLS-SEM using the SmartPLS 3.0 program, to measure the reliability of a construct with reflexive indicators can be done in two ways, namely Cronbach's Alpha and Composite Reliability. The construct is declared reliable if the composite reliability and Cronbach alpha values are above 0.70 (Ghozali \& Latan, 2015).

The structural model or inner model shows the relationship or the strength of estimates between latent variables or constructs based on substantive theory. In assessing the structural model, first assess the R-Square for each endogenous latent variable as the predictive power of the structural model. Testing of the structural model is carried out by looking at the R-square value which is the goodness-fit test of the model. Changes in the value of RSquare can be used to explain the effect of certain exogenous latent variables on endogenous latent variables whether they have a substantive effect. R-Square values of $0.75,0.50$ and 0.25 can be concluded that the model is strong, moderate and weak (Ghozali \& Latan, 2015). This f-square test was conducted to determine the goodness of the model. The f-square values of $0.02,0.15$ and 0.35 can be interpreted as whether the latent variable predictor has a weak, medium, or large influence at the structural level (Ghozali, 2015). The next test is to see the significance of the effect between variables by looking at the parameter coefficient values and the $\mathrm{T}$ statistical significance value, namely through the bootstrapping method (Ghozali \& Latan, 2015).

Testing the mediating effect in the analysis using PLS using the procedure developed by Baron Dan Kenny (1998, in Ghozali and Latan, 2015) with the following stages:

1. The first model, examines the effect of exogenous variables on endogenous variables and must be significant at t-statistic $>1.96$.

2. The second model, examines the effect of exogenous variables on mediating variables and must be significant at t-statistic $>1.96$.

3. The third model, test the simultaneous influence of exogenous and endogenous variables mediating.

In the final stage of testing, if the effect of exogenous variables on endogenous variables is not significant while the effect of mediating variables on endogenous variables is significant at $t$-statistic $>1.96$, then the mediating variable is proven to mediate the effect of exogenous variables on endogenous variables.

\section{Result and Discussion}

PT. Biro Klasifikasi Indonesia, which is the only national classification body, is required to be able to compete both in the national market and in the international market with foreign classification bodies. The PT. Indonesian Classification Bureau (BKI) was established to register commercial ships belonging to Indonesian citizens sailing overseas. Based on the data collected through the distribution of questionnaires to the respondents, it can be obtained an overview of the characteristics of the respondents who became the sample of this study. The number of respondents who became the source of data in this study amounted to 90 people. the respondent's position in shipping companies that have used the services of PT. BKI. The majority of respondents who have positions as managers in shipping companies are 46 respondents or equal to $51.11 \%$, respondents who have positions as shipowners are 14 people or $15.56 \%$, respondents who have positions as directors in shipping companies are 12 people or $13.33 \%$ and respondents who has a position other than ship owner, director or manager or others such as technical superintendent or operational of 18 people or $20 \%$. The positions with the most respondents are managers who have good knowledge and insight in the field of shipping and shipping. Characteristics of respondents based on years of service are divided into two categories, namely tenure of less than 5 years and tenure of more than 5 years. The majority of respondents have worked in shipping companies for more than 5 years as many as $86.67 \%$ or 
78 people, while respondents who have worked for less than 5 years are $13.33 \%$ or 12 people. The last education of the respondents is divided into three, namely Postgraduate / Masters / Doctoral Degree, Diploma / S1 and SMA / SMK. Table 5.3 shows that the education level of the most respondents is diploma / S1 at $75.56 \%$ or 68 people, SMA / SMK education is $15.55 \%$ or as many as 14 people and Postgraduate / S2 / S3 education shows the smallest result of $8.89 \%$ as many as 8 people. The education level of most respondents is diploma / S1 indicating a good level of knowledge in the field of shipping and shipping.

\subsection{Data Analysis Results}

Prior to data analysis, validity and reliability tests were first carried out on the scale used, this analysis was used to provide an overview of the object or research results related to the research respondents being studied. This analysis will explain the distribution of each variable, namely the dependent and independent variables.

\subsubsection{Descriptive Statistical Analysis}

In order to determine the tendency of respondents in answering questionnaire questions in the form of values (means), descriptive statistics were carried out.

Table 4.1. Descriptive Statistics

\begin{tabular}{|l|l|r|r|r|r|}
\hline Indicator & $\mathbf{N}$ & Minimum & Maximum & Mean & Std. Deviation \\
\hline KL1 & 90 & 3 & 5 & 4.438 & 0.609 \\
\hline KL2 & 90 & 3 & 5 & 4.427 & 0.608 \\
\hline KL3 & 90 & 3 & 5 & 4.469 & 0.612 \\
\hline KL4 & 90 & 3 & 5 & 4.448 & 0.610 \\
\hline KL5 & 90 & 3 & 5 & 4.417 & 0.672 \\
\hline CP1 & 90 & 3 & 5 & 4.521 & 0.595 \\
\hline CP2 & 90 & 3 & 5 & 4.604 & 0.530 \\
\hline CP3 & 90 & 3 & 5 & 4.531 & 0.594 \\
\hline CP4 & 90 & 3 & 5 & 4.667 & 0.514 \\
\hline CP5 & 90 & 3 & 5 & 4.708 & 0.498 \\
\hline CP6 & 90 & 3 & 5 & 4.542 & 0.519 \\
\hline CP7 & 90 & 3 & 5 & 4.479 & 0.595 \\
\hline CP8 & 90 & 3 & 5 & 4.521 & 0.540 \\
\hline KP1 & 90 & 3 & 5 & 4.646 & 0.520 \\
\hline KP2 & 90 & 3 & 5 & 4.604 & 0.530 \\
\hline KP3 & 90 & 3 & 5 & 4.667 & 0.514 \\
\hline KP4 & 90 & 3 & 5 & 4.719 & 0.534 \\
\hline \multicolumn{5}{|r|}{ Source: PLS Processed, 2021. } \\
\hline
\end{tabular}

From the table above, the minimum (min) and maximum (max) values for respondents' answers are 3 and 5 for all indicators of service quality (KL), corporate image (CP) and user decisions (KP).

\subsubsection{Test Measurement Model or Outer Model}

This study uses an individual reflective measure that is said to be high if it has a correlation of more than 0.70 with the construct to be measured. However, at the research stage of the scale development stage, a loading of 0.50 to 0.60 is still acceptable (Ghozali \& Latan, 2015).

Table 4.2. Convergent Validity Test

\begin{tabular}{|c|c|c|}
\hline Indicator & Loading Factor & AVE . value \\
\hline KL1 & 0.913 & \multirow{5}{*}{0.8448} \\
\hline KL2 & 0.895 & \\
\hline KL3 & 0.763 & \\
\hline KL4 & 0.943 & \\
\hline KL5 & 0.710 & \\
\hline CP1 & 0.745 & \multirow{7}{*}{0.767} \\
\hline $\mathrm{CP} 2$ & 0.778 & \\
\hline CP3 & 0.878 & \\
\hline CP4 & 0.800 & \\
\hline CP5 & 0.742 & \\
\hline CP6 & 0.721 & \\
\hline CP7 & 0.771 & \\
\hline
\end{tabular}




\begin{tabular}{|l|l|l|}
\hline CP8 & 0.701 & \\
\hline KP1 & 0.802 & \multirow{2}{*}{$\mathbf{0}$} \\
\cline { 1 - 2 } KP2 & 0.848 & \\
\hline KP3 & 0.895 & \\
\hline KP4 & 0.760 & \\
\hline
\end{tabular}

Convergent validity of the analysis results on the above table it can be concluded that all indicators of each construct has a loading factor values $>0.7$ and in table 5.5 can be seen that the value RD>0.5, it can be said that the instruments used in this study meets the criteria of convergent validity. This study uses a basic Ghozali \& Latan (2015) describes other tests to assess the validity of the construct by looking at the value AVE. The model is said to be good when the AVE of each construct value is greater than 0,50 .

Table 4.3. Cross Loading Value

\begin{tabular}{|l|r|r|r|}
\hline Indicator & $\begin{array}{r}\text { Quality } \\
\text { Service }\end{array}$ & $\begin{array}{c}\text { Corporate } \\
\text { image }\end{array}$ & $\begin{array}{c}\text { Decision } \\
\text { Use }\end{array}$ \\
\hline KL1 & $\mathbf{0 . 9 1 3}$ & & \\
\hline KL2 & $\mathbf{0 . 8 9 5}$ & & \\
\hline KL3 & $\mathbf{0 . 7 6 3}$ & & \\
\hline KL4 & $\mathbf{0 . 9 4 3}$ & & \\
\hline KL5 & $\mathbf{0 . 7 1 0}$ & & \\
\hline CP1 & & 0.745 & \\
\hline CP2 & & 0.778 & \\
\hline CP3 & & 0.878 & \\
\hline CP4 & & 0.800 & \\
\hline CP5 & & 0.742 & \\
\hline CP6 & & 0.721 & \\
\hline CP7 & & 0.771 & \\
\hline CP8 & & 0.701 & \\
\hline KP1 & & & 0.802 \\
\hline KP2 & & & 0.848 \\
\hline KP3 & & & 0.895 \\
\hline KP4 & & & 0.760 \\
\hline
\end{tabular}

Table 4.4. Fornell - Larcker . values

\begin{tabular}{|l|l|l|l|}
\hline alue Fornell - Larcker & $\begin{array}{c}\text { Corporate } \\
\text { image }\end{array}$ & $\begin{array}{c}\text { Quality } \\
\text { service }\end{array}$ & $\begin{array}{c}\text { Usage } \\
\text { decision }\end{array}$ \\
\hline Corporate image & 0.769 & & \\
\hline Service quality & 0.712 & 0.850 & \\
\hline Usage decision & 0.718 & 0.716 & 0.828 \\
\hline
\end{tabular}

Source: PLS Processed, 2021.

Reliability test is a test to measure the extent to which the results or measurements can be trusted or reliable and provide relatively consistent measurement results after several measurements have been made. The construct is declared reliable if the composite reliability and Cronbach alpha values are above 0.70 (Ghozali \& Latan, 2015). Furthermore, the results of the reliability test can be seen in the following table.

Table 4.5. Results of Cronbach's Alpha and Composite Reliability

\begin{tabular}{|l|c|c|l|l|}
\hline Variable & Cronbach's Alpha & Composite Reliability & Limit Value & Conclusion \\
\hline Corporate image & 0.901 & 0.920 & 0.7 & Meet the criteria \\
\hline Service quality & 0.900 & 0.722 & 0.7 & Meet the criteria \\
\hline Usage decision & 0.848 & 0.686 & 0.7 & Meet the criteria \\
\hline
\end{tabular}

\subsubsection{Structural Model Test or Inner Model}

The goodness-fit test of the model was carried out by using the R-square test. Changes in the value of RSquare can be used to explain the effect of certain exogenous latent variables on endogenous latent variables whether they have a substantive effect. R-Square values of 0,75, 0,50 and 0,25 can be concluded that the model is strong, 
moderate and weak (Ghozali \& Latan, 2015). The output results show that service quality affects the corporate's image by 0.507 or $50.7 \%$. Meanwhile, service quality and corporate image influence user decisions by 0.601 or $60.1 \%$.

Table 4.6. Results of R-Square

\begin{tabular}{|l|l|l|}
\hline \multicolumn{1}{|c|}{ Matrix } & R square & R square adjusted \\
\hline Corporate image & 0.507 & 0.502 \\
\hline Usage decision & 0.601 & 0.592 \\
\hline \multicolumn{2}{|c|}{ Source: PLS Processed, 2021 }
\end{tabular}

In addition to assessing whether or not there is a significant relationship between variables, a researcher should also assess the magnitude of the influence between variables with Effect Size or f-square (Wong, 2013). The $\mathrm{f}$ square value is 0.02 as small, 0.15 as medium, and 0.35 as large. Values less than 0.02 can be ignored or considered no effect (Sarstedt et al., 2017).

Tabel 4.7. F-Square Result

\begin{tabular}{|l|c|c|c|}
\hline \multicolumn{1}{|c|}{ Matriks } & $\begin{array}{c}\text { Corporate } \\
\text { Image }\end{array}$ & $\begin{array}{c}\text { Service } \\
\text { Quality }\end{array}$ & $\begin{array}{c}\text { Usage } \\
\text { decision }\end{array}$ \\
\hline Citra Perusahaan & & & 0.219 \\
\hline Kualitas Layanan & 1.028 & & 0.214 \\
\hline Keputusan penggunaan & & & \\
\hline
\end{tabular}

Source: PLS Processed, 2021

The value of the F square of service quality on the corporate's image has a value of 1.028 which means it has a very strong influence. While the corporate's image and service quality on user decisions have a fairly strong influence, which has a value of 0.219 and 0.214 , respectively.

Table 4.8 Q-Square Results

\begin{tabular}{|l|l|}
\hline Variable & Q Square \\
\hline $\begin{array}{l}\text { Corporate } \\
\text { Image }\end{array}$ & $\mathbf{0 . 2 6 8}$ \\
\hline Service Quality & \\
\hline Usage decision & $\mathbf{0 . 3 7 3}$ \\
\hline
\end{tabular}

Source: PLS Processed, 2021

In table 6.0 above, it can be seen from Q-square where the value of Q-square> 0 means the model has good predictive relevance. Based on the table regarding the Q-Square results, it shows that the value for the Corporate Image variable is 0.268 where the value is greater than 0 so it is declared good. For the usage decision variable of 0.373 where the value is greater than 0 so it is declared good.

\subsubsection{Estimate for Path Coefficients}

According to Hartono (2008, as cited in Jogiyanto \& Abdillah, 2009) explains that the size of the significance of the support for the hypothesis can be used to compare the values of the T-table and T-statistics. If the T-statistic is higher than the T-table value, it means that the hypothesis is supported or accepted. In this study, for a 95 percent confidence level (95 percent alpha), the critical value with a significance level of 5\% fault is 1.96. The PLS (Partial Least Square) analysis used in this study was carried out using the SmartPLS version 3.0 program.

Table 4.9 Path coefficient results and $P$ values

\begin{tabular}{|l|l|l|l|l|l|}
\hline & $\begin{array}{c}\text { Original } \\
\text { Sample }\end{array}$ & $\begin{array}{c}\text { Sample } \\
\text { mean }\end{array}$ & $\begin{array}{c}\text { Standard } \\
\text { Deviation }\end{array}$ & T Statistics & P Values \\
\hline Corporate image -> Usage decision & 0.421 & 0.426 & 0.092 & 4.593 & 0.000 \\
\hline Service Quality -> Corporate Image & 0.712 & 0.716 & 0.055 & 12,883 & 0.000 \\
\hline Quality of Service -> Usage decision & 0.417 & 0.414 & 0.093 & 4.469 & 0.000 \\
\hline
\end{tabular}

Source: PLS Processed, 2021

Service quality has a significant effect on service usage decision with a T-statistic value of 4.469 which means it is greater than 1.96 with a p-value of 0.000 . Meanwhile, corporate image has a significant effect on service usage decision with a T-statistic value of 4.593 which means it is greater than 1.96 with a p-value of 0.000 . It can be concluded that the three research hypotheses are accepted. 


\subsubsection{Mediation Hypothesis Test}

Table 4.10 Mediation Effect Results

\begin{tabular}{|l|l|l|l|l|l|}
\hline & $\begin{array}{c}\text { Original } \\
\text { Sample }\end{array}$ & $\begin{array}{c}\text { Sample } \\
\text { mean }\end{array}$ & $\begin{array}{c}\text { Standard } \\
\text { Deviation }\end{array}$ & T Statistics & P Values \\
\hline Corporate image -> Usage decision & & & & & \\
\hline Service Quality -> Corporate Image & & & & & \\
\hline Quality of Service -> Usage decision & 0.300 & 0.306 & 0.072 & 4.157 & 0.000 \\
\hline
\end{tabular}

Mediation hypothesis testing was conducted to determine the strength of the influence of moderator variables in this study. The results show that the mediating effect of the T-statistical value is 4.157 , which means it is greater than 1.96 with p-values of 0.000 . Shows that the mediator variable has a positive and significant effect on the relationship between the service quality variable and the decision to use.

\subsection{Hypothesis Discussion}

From the test results between variables indicate that service quality has a significant effect on corporate image, meaning that the better the quality of services provided by a service corporate, especially PT. BKI, the better the corporate's image will be. The test results of the PLS model show a positive and significant effect with a Tstatistical value of 12.883 and a p-value of 0.000 . The conclusion obtained from the acceptance of this hypothesis is that if all members in management, especially PT. BKI is able to work together in improving the quality of services in various aspects such as the availability of good physical evidence in the office, the ability and intelligence of employees, responsiveness of employees to customers and the surrounding environment, establishing good relationships with consumers will be able to improve the image of PT. BKI.

Service quality is closely related to consumer behavior in deciding whether to buy the product or service or not. Good and quality service is part of consumer assessment. Good service includes speed in serving and friendliness of employees. The better the services provided, the more influencing consumers to make purchases or use products or services. So the quality of service is perceived as good. Conversely, if the service received by consumers is not as expected, then the quality of service is considered poor. The test results of the PLS model show a positive and significant effect with a T-statistical value of 4.469 and p-values of 0.000 . PT BKI's service quality includes facilities, employees, technical staff, employees as a whole as well as fast and precise service that is in accordance with the wishes of PT. BKI.

A strong corporate image is able to stem the negative influence on the corporate so that it can keep consumers from turning to other competitors. By improving the corporate's image through the corporate's reputation, physical image and public relations can influence customers to use the corporate's services. PT. BKI has maintained the quality of its services well, has a good reputation, cares about the development of research in the maritime field, competitive prices, and also PTBKI is a world-class national classification body. Of course all these elements can convince consumers to use the services of PT. BKI.

PT. BKI has a good corporate image in the eyes of consumers. This is evident from the proof of the hypothesis that service quality affects the corporate's image. Optimal quality of services provided, the corporate's image which is a form of quality, reputation, and also consumer confidence will increase. This directly or indirectly will increase the consumer's decision to use PT. BKI. This can be a positive signal for consumers because they have satisfaction consisting of the services of PT. BKI and also continue to trust the corporate's image which is always maintained regularly by the corporate.

\section{Conclusions and Practical Implication}

\subsection{Conclusion}

Based on the results of research and discussion, the test results of all hypotheses stated that all hypotheses were acceptable and it was in line with previous research. So the conclusions of this study are as follows: Service quality has a positive and significant effect on the corporate image of PT. Biro Klasifikasi Indonesia (Persero). The conclusion obtained from the acceptance of this hypothesis is that if all members in management, especially PT. Biro Klasifikasi Indonesia (Persero) is able to work together in improving the quality of services in various aspects such as the availability of good physical evidence in the office, the ability and intelligence of employees, 
responsiveness of employees to service users and the surrounding environment, establishing good relationships with consumers will be able to improve the corporate's image PT. Biro Klasifikasi Indonesia (Persero).

Service quality has a positive and significant impact on the decisions of service users of PT. Biro Klasifikasi Indonesia (Persero). Service quality is closely related to consumer behavior in deciding whether to buy the product or service or not. Good service affects the decisions of service users which will have an impact on repeated purchases which means there will be an increase in sales. Good service includes complete and easy facilities, speed of service and friendliness of employees.

Corporate image has a positive and significant effect on the decisions of service users of PT. Biro Klasifikasi Indonesia. A strong corporate image is able to stem the negative influence on the corporate so that it can keep customers from turning to other competitors. By improving the corporate's image through the corporate's reputation, physical image and public relations can influence customers to use the services of PT. Biro Klasifikasi Indonesia (Persero). This is because PT. Biro Klasifikasi Indonesia (Persero) has maintained the quality of its services well, has a good reputation, cares about the development of research in the maritime field, competitive prices, and also PT. Biro Klasifikasi Indonesia (Persero) is a world-class national classification agency. Of course all these elements can convince customers to use the services of PT. Biro Klasifikasi Indonesia(Persero).

Corporate image mediates service quality on the decisions of service users of PT. Biro Klasifikasi Indonesia (Persero) because the results of the mediation effect showed positive and significant. PT. Biro Klasifikasi Indonesia (Persero) has a good corporate image in the eyes of consumers, this is evident from the proof of the hypothesis that service quality affects the corporate's image. Optimal quality of services provided, the corporate's image which is a form of quality, reputation, and also consumer confidence will increase. This will directly or indirectly increase the decision to use the services of PT. Biro Klasifikasi Indonesia (Persero). This can be a positive signal for consumers because they have confidence in the services of PT. Biro Klasifikasi Indonesia (Persero) and also continue to trust the corporate's image which is always maintained regularly by the corporate.

\subsection{Practical Implication}

The theoretical implications of the research are based on the theoretical research model in this study and the suitability of the model has been tested through PLS 3.0 analysis, so the results of this study can strengthen the theoretical concept of the variables that influence the decision to use the following implications:

The service quality variable has a positive and significant effect on corporate image, so hypothesis one (H1) which states that service quality has a positive and significant effect on corporate image is accepted. The results in this study support previous research conducted by Rohman (2018) which examined the influence of brand image and service quality on service user decisions, finding that service quality has a positive effect on brand image. The results of this study are supported by the results of research from Nicholas Wilson (2018) which shows that service quality has a major influence on brand image in the aviation industry in Indonesia.

The service quality variable is declared to have a positive and significant effect on the decisions of service users, so hypothesis two $(\mathrm{H} 2)$ which states that service quality has a positive and significant effect on the decisions of service users is accepted. The results in this study support previous research conducted by (Riyadh \& Nikmah, 2019) which examined the effect of service quality on usage decisions for customers of Raharjo Tour \& Travel Malang finding that service quality has a significant effect on service usage decision. Likewise with research conducted by Rachmawati et al. (2019) proves that the effect of service quality on service usage decision has a significant positive effect.

The variable of corporate image is declared to have a positive and significant effect on decisions to use services, so hypothesis three $(\mathrm{H} 3)$ which states that corporate image has a positive and significant effect on decisions to use services is accepted. The results in this study support previous research conducted by Wahyuni et al. (2020) which examined the effect of corporate image on service usage decisions on customers of PT Pos Indonesia (Persero) Semarang Post Office, which found that corporate image had a significant effect on service usage decision. Likewise with research conducted by Wilson (2018) which proves that the influence of corporate image on Lion Air ticket purchasing decisions.

The fourth hypothesis (H4) which states that the corporate's image is thought to mediate the relationship between service quality and service usage decision is acceptable. Because the results of the study indicate that the 
mediator variable has a positive and significant influence on the relationship between the service quality variable and the decision to use. The results in this study support previous research conducted by Souiden et al. (2006) show that corporate image is able to mediate the influence of customer loyalty on customer purchasing decisions. Likewise, the results of research Ningrum and Nurcahya (2014) found that the image of the corporate is able to mediate the effect of customer satisfaction on consumer purchasing decisions.

\section{References}

Fauzi, A. A., \& Suryani, T. (2019). Measuring the effects of service quality by using CARTER model towards customer satisfaction, trust and loyalty in Indonesian Islamic banking. Journal of Islamic Marketing, 10(1), 269-289. https://doi.org/10.1108/JIMA-04-2017-0048

Ghozali, I., \& Latan, H. (2015). Partial least squares konsep, teknik dan aplikasi menggunakan program smartpls 3.0 untuk penelitian empiris. In Semarang: Badan Penerbit UNDIP.

Giovanis, A., Athanasopoulou, P., \& Tsoukatos, E. (2016). The role of corporate image and switching barriers in the service evaluation process. EuroMed Journal of Business, 11(1), 132-158. https://doi.org/10.1108/EMJB01-2015-0002

Jogiyanto, \& Abdillah, W. (2009). Konsep dan aplikasi PLS (Partial Least Square) untuk penelitian empiris. Yogyakarta: BPFE.

Keni, K., Teoh, A. P., \& Muthuveloo, R. (2020). The impact of service quality and corporate reputation toward tourist loyalty: A study of the Indonesian hotel industry. Proceedings of the Tarumanagara International Conference on the Applications of Social Sciences and Humanities (TICASH 2019), 363-369. https://doi.org/10.2991/assehr.k.200515.064

Kotler, P., \& Keller, K. L. (2012). Manajemen pemasaran. Jilid 1 (12nd ed.). Jakarta: Erlangga.

Ningrum, L. S., \& Nurcahya, I. K. (2014). Pengaruh corporate social responsibility terhadap corporate image dan perilaku word of mouth. E-Jurnal Manajemen, https://ojs.unud.ac.id/index.php/Manajemen/article/view/7489

Omoregie, O. K., Addae, J. A., Coffie, S., Ampong, G. O. A., \& Ofori, K. S. (2019). Factors influencing consumer loyalty: evidence from the Ghanaian retail banking industry. International Journal of Bank Marketing, 37(3), 798-820. https://doi.org/10.1108/IJBM-04-2018-0099

Parman, P., \& Susanto, S. (2016). Analisis pengaruh kualitas pelayanan, kualitas produk dan citra merek terhadap kepuasan pelanggan dan dampaknya pada loyalitas pelanggan Waroeng Spesial Sambal. JBTI: Jurnal Bisnis: Teori Dan Implementasi, 7(1), 133-157.

Pasaribu, Z., \& Agung E, D. (2015). Pengaruh penggunaan media internal portal PT Dirgantara Indonesia terhadap citra perusahaan. Jurnal Sosioteknologi, 14(1), 61-70. https://doi.org/10.5614/sostek.itbj.2015.14.1.7

Rachmawati, D., Barokah, S. N., \& Nahar, M. (2019). Analysis of influence of price, service quality, brand image to customers'purchase decision of Korean Marine Transport CO., LTD. (A case study at PT. Samudera Indonesia Tbk. Semarang). JOBS (Jurnal Of Business Studies), 3(1), 27-38.

Rahardjo, M. (2017). Studi kasus dalam penelitian kualitatif: Konsep dan prosedurnya. Universitas Islam Negeri Maulana Malik Ibrahim.

Riyadh, M., \& Nikmah, F. (2019). Pengaruh kualitas pelayanan dan citra perusahaan terhadap keputusan pembelian jasa di Raharjo Tour \& Travel Malang. Jurnal Aplikasi Bisnis, 4(2), 490-494.

Rohman, A., \& Hatmawan, A. A. (2018). Analisis pengaruh citra merek dan kualitas layanan terhadap keputusan pengguna jasa pengiriman (Study kasus pada pengguna jasa JNE Express across nations cabang Nganjuk). Capital: Jurnal Ekonomi Dan Manajemen, 1(1), 1-16. https://doi.org/10.25273/capital.v1i1.2133

Sarstedt, M., Ringle, C. M., \& Hair, J. F. (2017). Treating unobserved heterogeneity in PLS-SEM: A multi-method approach. In Partial Least Squares Path Modeling (pp. 197-217). Springer International Publishing. https://doi.org/10.1007/978-3-319-64069-3_9

Siregar, S. (2013). Metode penelitian kuantitatif. Jakarta: Prenadamedia Group.

Souiden, N., Kassim, N. M., \& Hong, H. (2006). The effect of corporate branding dimensions on consumers' product 
evaluation. European Journal of Marketing, 40(7/8), 825-845. https://doi.org/10.1108/03090560610670016

Sugiyono. (2016). Memahami penelitian kualitatif. Bandung: Alfabeta.

Sugiyono. (2018). Metode penelitian kuantitatif, kualitatif, dan R\&D. Bandung: Alfabeta.

Sugiyono, S. (2017). Metode penelitian kuantitatif, kualitatif, dan R\&D. Bandung: Alfabeta.

Wahyuni, R. C., \& Waloejo, H. D. (2020). Pengaruh kualitas pelayanan, harga, dan citra perusahaan terhadap keputusan penggunaan jasa PT Pos Indonesia (PERSERO) Kantor Pos Semarang. Jurnal Ilmu Administrasi Bisnis, 9(1), 349-356.

Wilson, N. (2019). The Impact Of Service Quality And Brand Image Toward Customer Loyalty In The Indonesian Airlines Industry. Jurnal Manajemen Indonesia, 18(3), 222-234. https://doi.org/10.25124/jmi.v18i3.1734

Wong, K. K.-K. (2013). Partial least squares structural equation modeling (PLS-SEM) techniques using SmartPLS. Marketing Bulletin, 24(1), 1-32.

Yudiana, F. E., \& Setyono, J. (2016). Analisis corporate social responsibility, loyalitas nasabah, corporate image dan kepuasan nasabah pada perbankan syariah. Inferensi, Jurnal Penelitian Sosial Keagamaan, 10(1), 93-114. https://doi.org/10.18326/infsl3.v10i1.93-114 